\title{
EIGHT KEYS BEFORE LEARNING TO SPEAK ENGLISH: (A Proposal for Motivating EFL Speaking Learners in Indonesia)
}

\author{
Oleh: Abdul Wafi \\ (STAI Al-Khairat Pamekasan/E-mail: Abdulwafi81@yahoo.com)
}

\begin{abstract}
:
Being able to speak English fluently is as measuring rod for someone who is said to be good at English. In Indonesian context, English is still as foreign language and this becomes problem for them who want to learn it. The problem could be caused by the difficulty of the English itself, the learners' personality and the process in learning it. There are ample solutions to deal with those difficulties; however, the writer provides a solution as a proposal for motivating the learners; there are 8 keys to be possessed by the learners before they learn to speak English. They are (1) Listen up, (2) be good at imitating, (3) use the mouth, (4) check the voice, (5) have the motion, (6) smile, (7) thank God, and (8) love. The solution is as inner drive or instrinsic motivation for the learners and it can also be used by the teachers, tutors and lecturers as reference for motivatingthe learners in learning or in mastering English speaking.
\end{abstract}

Keywords:

Speaking, Foreign language, Inner drive, Motivation

\section{Introduction}

Speaking is considered as the most significant ability in learning a language. Naturally, humanin general, is able to result ten thousands words in a day and this makes speaking as a part of their daily life. Of its most importance, they forgot how they were in labor to be able to attain their speaking ability ${ }^{1}$. Being able to speak English fluently and well is as the measuring rod for someone who is skillful at English. Someone who is said to master English refers to them who are able to communicate English verbally. And,

${ }^{1}$ Thornbury, Scott. 2005, How to Teach Speaking. Oxford: Macmillan Education. most of people who learn English are surely interested in learning to speak English orally.

In Indonesian Context, English is still as Foreign language. Gebhard ${ }^{2}$ states that English as foreign language means that it is learned by people where English is not their first language. It is only taught as a school subject. People do not use it as lingua franca within their daily communication. 
Furthermore,

Kachru $^{3}$ categorizes the country, that uses English for various businesses but they do not make it as dominant language in daily communication, into Expanding Circle Countries. The countries that are included in this category make English as their foreign language. This is different from English as second language and first language. The countries, such as America, England that use English as first language, are categorized into Inner Circle Countries. Meanwhile, the countries, such as India, Singaporethat use English as second language, are categorized into Outer Circle Countries.

\section{The problems in learning to speak} English

Of the position of English as foreign language, it appears several problems encountered by the learners. Those problems could be from (a) the English itself which is said to be really complicated, (b) the condition of the English learners which they have different characters and personalities, and (c) the process or the the strategies they use which are oriented to master English and or to learn it. It is said that English is really complicated language for it has various patterns in its grammar and its pronunciation is really unique. Even, English is said as a badly spelled language.

${ }^{3}$ Kachru, Braj B. 1992. World Englishes: Approaches, Issues, and Resources. Language Teaching 25.1 (1-14)
Beside that, the personality the language learners have will determine the success of their English learning. Lightbown and Spada ${ }^{4}$ state that the language learners who have introvert personality will be different from them who have extrovert personality. The introvert ones tend to be shy and reluctant in practicing and showing their speaking performance. They tend to be silent and passive in their verbal language. Meanwhile, the extrovert ones will appear more confident, assertive and adventurous in learning their speaking. They tend not to care with their mistakes and weaknesses. Different from Dulay et.al. ${ }^{5}$ concludes that the self confident, secure person is a more successful language learner.

In learning English, which its orientation is to be mastered and or to be learned, will show different result in the level of the success of enabling to speak. Dulay et $\mathrm{al}^{6}$ make distinction between learning English and mastering English. Learning English to be mastered is where its process of the learning should be made as natural as possible with the emphasis on 'fluency' and meaning. In its point is how the speaking can be understood although its grammar, its diction and its pronunciation are not correct.

\footnotetext{
${ }^{4}$ Lightbown Patsy M, \&Spada, Nina. 1999. How Languages Are Learned. Oxford: Oxford University Press. (pp. 54-56)

${ }^{5}$ Dulay, Heidi, Burt, Marina,\&Krashen, Stephen. 1982.Language Two. New York: Oxford University Press. (pp.74-75)

${ }^{6}$ Ibid (pp.14-20)
} 
Meanwhile, learning English to be learned is where its process of the learning should be made as formal as possible with the emphasis on 'accuracy' and the form of the language.In a nutshell, whenever and wherever the learners practice and perform their speaking, they must pay attention to the correctness in their grammar, pronunciation and its dictions.

In addition, Brown ${ }^{7}$ distinguishes the term 'fluency' and 'accuracy' by using the term 'message oriented' and 'language oriented'. Message oriented is teaching language use. Meanwhile, leanguage orientedis teaching language usage. In message oriented means the teaching of speaking by focusing on using the language as to convey message while in 'language oriented' means the teaching of speaking by focusing on how the language is used.

\section{Solution: A Proposal for Motivation}

There are ample ways and solutions to deal with those problems in mastering and or learning English. Various efforts have been highly conducted to give assistant to the English learners in attaining and improving their speaking. The governement, linguists, lecturers, teachers, tutors and the owners of English courses have given their best effort to succed the english learning in

\footnotetext{
${ }^{7}$ Brown, H. Douglas. 2001. Principles of Language Learning and Teaching (2nd Edition). New York: Addison Wesley Longman, Inc(pp.
} 269) improving their speaking performance. The sophisticated teaching and learning media have been available in everywhere; internet access, audio and video files as supportive tools are easy to get.

However, in this article, the writer proposes a solution for the English learners in enhancing their speaking skill. This solution or simply said ' 8 keys before' is as the revision of '7 things before $^{\prime 8}$. It is focused on the giving motivation to the English learners particularly the beginners in mastering English. Motivation ${ }^{9}$ is defined as the extent to which someone make choices about goals to pursue and the effort they will devote to that pursuit. Giving motivation to EFL learners is a must ${ }^{10}$. In schools, it is found that many students are in low motivation that affects to their achievement.This solution is as inner drive for the English learners to possess and to carry out before they decide to start learning to memorize, to arrange vocabulary items, and to reveal their idea verbally.

The inner drive or in Brown's term 'Intrinsic motivation' ${ }^{11}$ is as a very

\footnotetext{
${ }^{8}$ Wafi, Abdul. 2015. Terapi Ngomong Inggris: Jalan Pintas Bisa Berbicara Bahasa Inggris. Yogyakarta: Pustaka IImu. (Pp. 10-19)

${ }^{9}$ Brown, H. Douglas. 2001. Teaching by Principles: An Inteactive Approach to Language Pedagody (2nd Ed.). New York: Addison Wesley Longman, Inc (pp.72)

${ }^{10}$ Karim Mattarima and Abdul Rahim Hamdan, 'Learners' Motivation And Learning Strategies In English Foreign Language (EFI) In Indonesian Context" 1 (September 2011): 100 108.

${ }^{11}$ Ibid (Pp. 59)
} 
effective thing to be owned by someone for it is based on their own need, willingness and desire that enable them to do and accomplish what they want to do. If every English learner has that intrinsic motivation to learn and to master speaking, surely, they will always be enthusiastic in doing and accomplishing their tasks in enhancing their verbal language. They will volunteer in doing anything because they want it. Even, they probably do not need teacher to insist them to speak for they are willing to speak. Teachers do not need to dictate them what to do because they have had their desire to do. The English learners with intrinsic motivation will become autonomous learners and they are ready to enjoy their learning process joyfully.

In addition, this solution can be used by the lecturers, teachers and tutors who teach speaking to motivate their students to practice their speaking. It can be as a threshold step to be highly paid attention and and to be emphasized if they want to make their students able to master speaking English faster and more fluently. The teachers should give this ' 8 keys before' in the first meeting of their class so that their students can have effective 'weapon' to master speaking English. The followings are the 8 keys to have before learning to speak English:

\section{Listen up}

Listening is ear activity. English has two words which refer to this activity; they are 'listen' and 'hear'. However, both words can be differently defined. It lies in its process. The process of 'hear' takes place in every time the sound wave is caught by ear drum automatically and uncontrollably. Meanwhile, the process of 'listen' occurs after the process of 'hear'. It refers to analyzing and explaining the content of the sound wave in the brain into meaning and message. In another word, 'listen' is hearing attentively to gain meaning and message from what we are listening ${ }^{12}$.

In the sequence of language skills, Listening skill is coming before speaking skill. Listening is a receptive skill. In the process of listening, we receive message and manage it to be revealed in the act of speaking. In the act of listening, we collect information into our memory that later it can be topic for speaking. Listening is an easy activity to do as long as we are not deaf. By keeping on listening to english files, our ears will be more sensitive and unconciously we are able to pronounce and reveal what we have listened.

As an example of how effective the frequency of listening in enabling someone to speak is the writer's personal exprerience when he was in the fifth class of elementary school. He did not know English at all. In that time,

${ }^{12}$ Childs, Leslie. 1999. Academic Studies English: Support Material for Materials and Exercises for Speakingand Listening, 1st ed (a module). Canada: The national Literacy Secretariat of human Resource Development 
he had not electronic devices such as TV, tape recorder moreover computer. Only the rich people could afford to buy and have them all. Luckily, the writer had a rich friend who used to sing English song when he played together with him. His friend's favorite English song was 'Goodbye'-one of Air Supply's song.The writer liked the song very much for he was used to listening to the song that unconciously he was able to sing it well without knowing the meaning and writing.

This is also happened to little children who have not had ability to speak a language. Every day and every time they listen to the people around them talk to them and teach them to speak. And as the time goes bye, they can speak slowly, faster and after going through various process with mistakes, they finally can speak.

\section{Be good at imitating}

A little child is able to speak fast becuase he is good atimitating. $\mathrm{He}$ imitates everything he listens. With his innocence, withoutbeing shy and reluctant, he spells, utters and imitates exactly the same with what he sees and hears. He keeps doing it and finally he can speak it by using all his abilities.

This is in line with Asher's opinion in Brown ${ }^{13}$ stating that children who learn their first language; they do a

\footnotetext{
${ }^{13}$ Brown, H. Douglas. 2001. Teaching by Principles: An Inteactive Approach to Language Pedagody (2nd Ed.). New York: Addison Wesley Longman, Inc (pp. 30)
}

lot of listening activities before they speak and when they are in the act of listening, they follow it with physical responses which they get from imitating the people around them.

Different from teenagers and adults; the adult learners start to be more reluctant and shy to imitate. They tend to keep their good image and hesitate to imitate the people around them. This condition can hamper them in mastering speaking. The shame, reluctance, and worries have restricted them to express their speaking freely and joyfully. The more we are able to imitate, the more active and fluent our speaking will be. Watch English movies then imitate all the good things on it especially things related to improving our speaking. If the actor of the movie shouts, then just shout as he shout. If the actor of the movie speak in sadness and cry, just cry as he cries. Imitate all his style of speaking, facial gestures, eyes sight, body language and so forth. When we see robot speaking, just speak as like it. When we see a monkey walking, just walk as like it. Do it more and more. Finally, our style of speaking will become more attractive and fluent without being restricted by feeling of shy, reluctant and afraid. And, we can be more confident in revealing our ideas verbally.

For speaking teachers, having fluency and attraction in expressing their teaching are very needed in order to their students become more enthusiastic and motivated in enjoying the learning. 
The students can have a good model to be imitated. The attractive teachers will make their students become active while if the passive teachers will make their students passive. Futhermore, Asher in Brown compares the speaking teacher as like a director and the students are as his actors. ${ }^{14}$

\section{Use the Mouth}

The paramount key to be able to speak a language is our 'mouth' for speaking is a mouth action. Simply said that people who do not have mouth can not speak. How often we use our mouth will determine that we can speak a language. The more we use our mouth to speak English, the more fluent our speaking English will be. Or, the more we use our mouth to speak Indonesian language, the more fluent our speaking Indonesian language will be. Suffice to say that It is impossible for us to be able to speak if we just use our hand and eyes for all of the time. It is because our hand is used for writing. The more we use our hand to write, the more fluent our writing will be. Mouth is the paramount tool in learning to speak.

Every one has their own mouth and no one else has right to touch others' mouth to force them to speak. Every one has their own right to utilize their mouth to say what to say and not to say what not to say. Everything depends on their own willingness and desire to open their mouth and start learning to convey their verbal message gradually.
No matter how great the teachers, lecturers, tutors even the native speakers teach us to speak English but if we just zip up our lips without saying a word; we will not be able to speak English. No matter how long we join English course and training, we will not be able to reveal our idea verbally if we just lock up our mouth.

If a day consists of 24 hours, then how many hours do we spend our time to use our mouth to speak Englis? Being fast or being slow our speaking mastery is dependent on how long we use our time. If we use 1 or 2 hours a day to practice our speaking, we will be able to master our English speaking but it is very slow. If we use 3 or 4 hours a day to speak English, we will be able to speak English faster than just spending 1 or 2 hours of our time. If we use 5 or 6 hours a day to use our mouth to speak English, we will be able to speak English faster than just spending 3 or 4 hours a day.

But, if we want the very fast speed to master our English speaking, use our 24 hours of a day, 7 days in a week, 4 weeks in a month to continue practicing our speaking, listening to English audio files, watching English movies, reading English novels and magazines, and writing anything in English. Use all of our time to be in Environment though it is confusing in the beginning but eventually we will be able to have a good understanding and good speaking proficiency. Then, how if we just use our mouth in only 1,5 hours in a

${ }^{14}$ Ibid. 
week to practice our speaking?How if each student is provided only 30 minutes in a week to practice their speaking as what happen in our school? Probably we can guess the answer as well as we can predict the result.

\section{Check the voice}

Our voice may affect the intelligence of our brain nerves in responding or in working to arrange or to remember the words. There are two kinds of voice ${ }^{15}$; they are (1) Weak voice (unpowerful voice) and (2) strong voice (powerful voice). The character of weak voice usually appears when we are sad, bad-mood, sleepy, exhausted, bored, sick and the like where it can make the brain nerve respond a bit slowly. While, the character of powerful voice appears when we are happy, motivated, fresh, healthy, and falling in love. Th powerful voice will make the nerve of our brain work more brilliant and more active in giving response. Basically, we do not need to shout or scream to have a powerful voice, but when we are speaking we have it with strong intention and enthusiastic to pell and pronounce the words we say. We have to believe in ourselves that other people need our clear speaking and we want to make them satisfied with the meesage of our speaking.

In a nutshell, if we want to be able to speak English quickly and

${ }^{15}$ Wafi, Abdul. 2015. Terapi Ngomong Inggris: Jalan Pintas Bisa Berbicara Bahasa Inggris. Yogyakarta: Pustaka IImu (pp. 11-12) fluently, just don't try to be silent. Don't be shy and don't be afraid. Show your motivated and loud voice for the sake of better fluent speaking. Even if we want to, we can train our speaking by speaking while shouting or speaking as like an angry man in order to our mouth and our brain can be active and eventually they can make our speakingattains its fluency. Just do not care though our speaking is at random in the beginning; just show up our powerful voice and keep talking with the English we have and keep learning and adding our vocabulary that in the end our speaking becomes better and more fluent.

\section{Get your motion}

By accompanying with motion when we are in the act of speaking will aid our brain to work and respond brilliantly. The definition of motion, according to Cambridge dictionary, is the act of process of moving, or a particular action or movement ${ }^{16}$. However, to make it more specific, the motion in this case is the motion as like hand gesture, facial gesture and body language.

There are two kinds of motion; they are (1) slow and weak motion, (2) fast and powerful motion. Slow and weak motion is the motion of unmotivated people, the drunkard, the sick people, the thirsty and the hungry

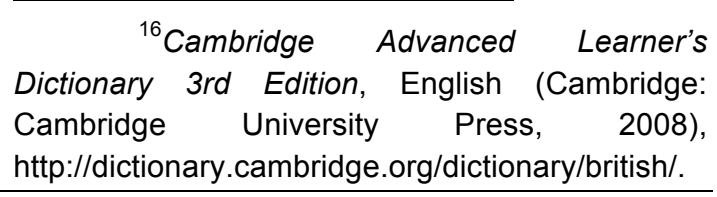


people who lost their power and the motion of the people who lost their hope. Meanwhile, the fast and powerful motion is the motion of the enthusiastic people, the confident people, the fresh and healthy people and the motion of the people who have strong willingness and desire to reach better success. The way we walk and they way we move our hand and our body will give effect to our brain's work. The slow and weak motion will make our brain work and respond slowly while the fast and powerful motion will make our brain work brilliantly and actively. So, help our brain in working to arrange the sentence or to memorize the vocabulary items we memorized by getting accustomed to having fast and powerful motion anytime we move.

Besides, by having hand and facial gestures with body language in the act of our speaking, it will make our interlocutors easier to understand the message of our speech and our speaking style will become more attractive. Our speaking style will not be boring and the people we are talking to will be enthusiastic in paying attention to our speech for we speak enthusiastically as well. In short, by accompanying with meaningful motion in the act of our speaking, our speaking performance will look more interesting and our speech will be attractive, flexible and sociable.And when we become a public speaker, we will look as a confident public speaker.

\section{Smile up}

A smile has a very significant role in our life. With a smile, it will make us comfortable and relaxed in facing trough our life. Islam teaches us that a smile is a charity and worship as prophet Muhammad said, "Your smile to your brother's face is charity ${ }^{17 "}$ Furthermore, prophet Muhammad said that smile has many benefits for our health; it can be medicine for heart, mind and soul as in his hadist "Never burden over your soul with the seriousness of life. Cheer up your life with something relaxed and funny because if the soul is often burdened with heavy problems, it will be dirty then"18

According to medical science ${ }^{19}$, a happy and sincere smile, which it is the beginning of laughter, enables to cure several diseases such as stress, high blood pressure, heart attack and it can also make us stay young.Of its benefits, it can boost immune, enhance resilience, improve mood, ease anxiety and fear and add joy and zest to life. In social benefits, a smile can be the first polite step in having social interaction particularly with new people we meet for itindicates that we are a friendly and welcoming person. It also helps defuse

\footnotetext{
${ }^{17}$ one of hadist narrated by Atturmudzi in hadits arbain (http://haditsarbain32.wordpress.com

${ }^{18}$ http://zona-

manfaat.blogspot.co.id/2015/01/manfaat-senyumdalam-islam.html (accessed on November 23, 2015.
19"Laughter Is the Best Medicine: The Health Benefits of Humor and Laughter," accessed November 23, 2015, http://www.helpguide.org/articles/emotional- health/laughter-is-the-best-medicine.htm.


conflict and strengthen relationship. On the contrary, being sullen will only make our days gloomy and miserable.

Of the benefits of smile is helping to make the nerve of brain to work. With sincere and happy smile, our brain will be more relaxed. Meanwhile, being sullen will make our brain tense that it gets difficulty to wrok well and brilliantly.

Then, what is the relationship between smile and learning to speak English? A wise word said, "Face with asmile no matter what happen". It means that we have to put a smile on our face in everything happen in our life. As an example, when we are learning English; our teacher then commands us to memorize 100 new words. So, just smile up and say "Ok sir, I'll try"; this will make our brain become more relaxed because of our positive reaction. Different from when we are directly sullen and inserted with the words "wow, it's so difficult", "I can't", it's impossible for me to memorize 100 words"; So,our brain nerve will not able to work well because our negative reaction towards the command. Another example is when we do mistake in grammar or pronunciation; try to smile up and stay cool and say "oops, sorry!, beginner!" this will make our brain more relaxed and we can be more confident to keep learning and improving our speaking ability.

One thing that we also have to know that the more we do mistakes in learning English the closer we will be to the correct ones. And even if we do mistakes in grammar or we are lack of vocabulary items; God will not enter us to his hell. So, just do more mistakes then we will come closer to the right things by the condition that we have willingness to continue learning from the mistakes we have done.

\section{Thank God}

Thanking to God (Allah) means we take everything for granted and always continue doing the best as we can for the sakeof our better qualifiedlife. Thanking means never complain for what we have and never blame the condition. Thanking to God means continue trying to see the bright side of everything happened and of everything we have attained. Thanking to God means never insult and regret for what have just happened.

Thanking to God can be (1) with word; namely by enriching of saying 'Alhamdulillah' and can be (2) with action; namely by practicing and utilizing what has been granted by Allah with the purpose of improving our worship and our good deed. People who are good at thanking to Allah will have tranquil, happy and harmonious life. Their life is always full of cheerfulness as if there were no burden. Every problem and weakness are taken as a challenge to face through with full of sincerity.

According to the expert, people who are good at thanking to God will have better health and better intelligence than people who complain their life for all of the time because they who like thanking to God will have peaceful and 
balance life and they will always be in positive thinking and that will make the nerves of their brain become active and brilliant. Meanwhile, people who like complaining and blaming the situation will only make the nerves of their brain become strained and tense because of their negative attitude in complaining and blaming the stituation. People who like complaining in their daily life and blaming the situation will have stressful and confusing life. Their heart will always be dry and they never feel any satisfaction. They will take all their life problems and their weakenesses as burden making their life really hard to walk through.

Islam teaches that all the things around us can be blessing and mercies or they can be a test and disaster for us. As a matter of fact, the blessings of Allah upon us are countless ${ }^{20}$. we will never be able to count every little thing of Allah's blessings and mercies bestowed to our life as Allah said, "And If you would count the blessings of Allah you would not be able to count them..." [Surah Ibrahim 14:34]. In another surah, Allah command us to always thank to him for what he has given to our life as he said, 'and (remember) when your lord proclaimed: "If you give thanks, I will give you more. But if you are thankless, verily, my punishment is indeed severe"[lbrahim; 7].

20"Giving Thanks to Allah Is a Blessing Al Quran Classes," accessed November 23, 2015, https://www.alquranclasses.com/givingthanks-to-allah-blessing/.
If we relate the surah to our learning English, do we always thank to Allah for we are able to use our mouth to say English? Do we thank to him for we are able to use our eyes to see dictionary, our ears to listen English file, our hand to write English writing, our brain and memory to think and to remember the words we have memorized? How many times we thank to him for the new knowledge and information we have got in every day? Probably we do not always say alhamdulillah for every progress we have and we seldom practice and share what we have learned. Probably, one of Allah's punishment for us is making us often forget the vocabulary we have memorized and our brain is made exhausted and difficult to understand what we learn.

In learning English, thanking to Allah has a vvery important role because it can help us more relaxed and easier in enjoying the process of learning. As an example, when our teacher commands us to speak English in front of our classmates; and we respond our teacher's command by saying secretly in our heart 'Alhamdulillah, he gives me a great opportunity to improve my speaking'. This attitude will probably make us more relaxed and we are not burdened by the weakness we have.Different from when we react negatively to our teacher's command by saying "No sir, my speaking is very bad. I am not confident and I am shy enough to speak in front of my classmates. It's 
difficult for me sir. My grammar is very bad as well as my pronunciation"; those hopeless sentences will only make our brain hopeless and unable to work well and brilliantly that we will be in difficulty to remember and arrange the words.

By thanking to Allah, we will always see the bright side of every thing happen to us then we will be more confident. We will focus on the strength we have and we take the weakness for granted. Though our vocabulary items are less, we will say, "it's ok. I still have my brain to think and memorize them", though our pronunciation is bad, we will say, "It's ok, I still have my mouth to train my bad pronunciation", though our grammar is not good, we will say, "It's ok, i still have many grammar books to read and I still have my grammar teacher to help me"

With such attitude, we will be more wise and relaxed in enjoying the process of mastering speaking. We will not make the weakness and difficulty in grammar, vocabulary and pronunciation as a burden in our learning. We will take all those difficulties as challenge to face. The Thankfulness in action can be conducted by practicing every English knowledge and information we have got in our daily life. We can practice it in both verbal and written language. And if we practicewhat we have known, Allah will teach another knowledge we do not know; as prophet Muhammad said in his hadist which is narrated by Imam Ahmad, "whoever practices the

knowledge he knows, Allah will give him another knowledge he does not know"

\section{Love}

Lexically, love is defined as strong liking for something ${ }^{21}$ or a great interest and pleasure in something. It is the antonym of hate. Many experts have defined and portrayed love; love is life, love is source of inspiration, love is a gift and sacrifice, love is power, love is a chemistry, love is a passionate commitment ${ }^{22}$.Love has a great power and its power could turn impossible thing become possible; it also could turn the disability to be ability; it also could turn the weak to be the strong; it also could turn the hopeless to be the enthusiastic.

By making the feeling of love as a basic in doing something, it will make everything seem easy and beautiful. As like when we are falling in love with our husband/wife, it seems that everything in him/her beautiful and perfect and we are willing to do anything for the sake of his/her happiness though we are sleepy and tired even when we are sick we are still trying hard to do the best for someone we love. Probably it is true what an aphorism said that when we are falling in love, everything looks sweet and perfect ('the cat's feces will taste chocolate')

${ }^{21}$ Cambridge Advanced Learner's
Dictionary 3rd Edition.
${ }^{22} \mathrm{Jim}$ Al-Khalili et al., "What Is Love?
Five Theories on the Greatest Emotion of All,"
The Guardian, December 13, 2012, sec.
Comment is
http://www.theguardian.com/commentisfree/2012/
dec/13/what-is-love-five-theories.


Coming up a question on the learning of English at secondary or high school or even at university which is stated that the result is not satisfactory. Probably one the factors of the 'failure of the English learning due to English subject is taken as a hated subject. The students do not like English. Their hatred to English is due to various factors.

If the unable to speak english fluently is as a disease, is it true that it is their main diseases? Or are they hiding behind their real main disease? If the students who do not like or love English and the teachers teach them and ask them to speak English and they cannot speak English; then which one should the teacher heal first? Their speaking or their hatred to English? Probably we all have the same answer that teaching English for the students who do not like English is teaching how to like it not to master it. Heal their hatred and make them like English then we can teach them to speak English. And surely, we do not need to force them to practice their English as long as they love it to.

Then, why does English become a hated subject at schools? Why do many students feel difficult in speaking English and easy to be hopeless in mastering it? Probably it is because of ample factors. One of them is the teachers. The teachers show their fierce and vicious teaching and probably they focus too much on accuracy. Another factor is due to monotonous teaching media, monotonous classroom atmosphere, and monotonous teaching technique.

So, how if we have gone too far in hating English? How to make the haters of English become the English lovers? There are several ways to appear the feeling of love in learning or mastering English; they are:

\section{a) We have to need it}

We will not love someone if we do not need him/her. No matter what motives we have; do we need his money, attention, affection, and the like. The feeling of need will create the desire and the desire will make everyone willing to do what he should do to reach what he wants to. In learning English, the feeling of neeed will appear when we know the advantage of mastering English. After we know its advantage, we will want it to. The more we see the advantages of having English, the more we want to master it. The more we want to master it, the stronger and harder our effort to reach it. So, ask our selves, what do i study English for? What is the benefit for me, for my life, for my future?

Sometimes, when we are in a dead end of a situation forcing us to master English, we will be willing to do anything to attain it no matter what happen. For instance, when we apply for our dream job; we want that job so much. However, we are blocked by one requirement that it is a must to have TOEFL certificate and pass the English interview. The time limit is only a month. Probably there will be two options-(1) 
trying as hard as possible to master English speaking and pass the TOEFL test or (2) finding another job vacancy which there is no such requirement. If we need it, we will try hard to get it. If we do not need it, just leave it.

\section{b) Be often to be with it.}

Like in a Javanese aphorism stating that "Witing tresno jalaran soko kulino" (the feeling of love will grow as the frequency of getting together). So, try to get accustomed to joining in an environment where English is daily used there such as English clubs, English courses, English dormitories and other English communities. By being there as often as possible, meeting with the peoplehaving the same goals, we will be contaminated by their zest in mastering English. Our love to English will get stronger because we are joining with the people who have the same interest with us. We will know what English is. And if we know it, we will love it.

\section{c) Find something or someone who can give support in mastering it}

In life,we still need help and support from others. When we are sad and unmotivated, we need advice and motivation from the people around us. Sometimes, people are willing to meet a psychologist, doctors, scholars to only ask suggestion and solution for their problems and even they are willing to pay a lot of money in return to getting the zest of life.
If we do not have enthusiasm in mastering English, then we need to find something or someone enabling us to be enthusiastic in mastering English. For instance, probably we will be motivated when someone we loveparents,children, spouse, best friends, teachers, always give support to us to master English. Do ask motivation and support from them that we are able to enjoy the process of learning patiently and successfully.

\section{d) Just do it for someone we love}

Someone is willing to struggle and continue fighting for reaching his dream becuase of some factors and one of them is for the sake of giving and doing the best for his beloved one. As an obidient child and loving our parents, surely we do not want to disappoint them for they have given their best for us. Our mother has born us, taken care of us and brought us up till now.

Our father has been working hard to find money and to fulfill our daily need. They send us to schools, buy us dresses and give us food; they love us and give their affection sincerely.

When we are exhausted, lazy and probably hopeless in learning or mastering English, just remember our parents' face especially our mother's face. Just remember their struggle and sacrifice. We are here because of them. Just keep in our mind about how much time, money and power they have struggled for the sake of our best. How much sufferings they have encountered 
for fighting for our happiness? Do we have any heart to let them down becuase of our failure? Do we still ignore their struggle and sacrifice for our success? Just do our best as hard as possible to make our parents happy and proud of us. Keep fighting and being patient in mastering or learning English although we are in tiresome, reluctance and laziness or probably in despair. Just bear in our mind that they are waiting for our success. If we do not want it, then do it for them then our life will be full of blessings and mercies.

\section{e) Pray to God}

As our prophet said in his hadist, "A prayer is the weapon of Muslim". By praying to Allah, we will be more sincere in facing through our life as well as we become more sincere in enjoying the process of our learning. By praying, we admit that there is no power and no effort to reach and make our dream except it is on Allah's permission. As Allah said, "Ask me, then I will give it to you"

For us who has hatred to English subject and we have been trying to love it, pray to Allah honestly.Ask Allah specifically in order to be given spirit and motivation to learn or to master English. Ask him that we have interest and love to English. pray to him that we are given intelligene and understanding all the lesson we have learned and the easiness to remember all the vocabulary items we have memorized. Ask him in order to be given fluency in speaking.
For us who are easy to be forgetful of what we have been memorizing and learning and for us who want to have better intelligence, it is highly suggested to read the following supplication: "Dear Allah, I entrust you of everything I have seen, I have written, I have heard, I have memorized, I have read and please give it back to me anytime I need it'. Please read the supplication in everytime we have finished studying, seeing, listening, reading, and memorizing all the things about English.Read it devoutedly and sincerely; In shaa Allah, he will bestow us good intelligence which we have never had before. Sometimes, we have done our effort to learn and to master English; we have memorized so many vocabulary items; we have been in labor to remember all the things about what we have learned; however, probably there are too many things our brain to remember and frequently we are easy to forget them.

By entrusting the knowledge to Allah as the creator of our brain, Allah will help us to remember and recall the knowledge we have had. Of the benefit of that supplication, we will often remember everything we need to remember spontaneously. We will often say "I think I have seen this on the board", "Well, I think I have memorized it", "I guess I have written this on my book", "I think I have heard this from my teacher". Simply said that we probably do not need to force our brain to remember all the things we have to, but 
the most important one is that as long we need we know it and we remember it.

\section{Conclusion}

Being able to speak English fluently become a most wanted thing by the English learners for it is as a measuring rod for someone is said to be good at English. However, within the process, they are not really in the right step to learn and to master English. There are things to have and to do before deciding to start learning and mastering English known as '8 keys before'. The first, they have to listen a lot to English files, the second they have to be good at imitating and the third is as the paramount key to speaking by being often to use their mouth to keep talking in English. The fourth key is they have to pay attention to their voice namely by having powerful voice in saying their English. The next key is they accompany their speaking with powerful motion such as gestures and body language. The sixth key is always facing and responding everything with a sincere smile and never forget to always thank to Allah for what they have got and they have done. And as the last key, they have to make the 'love' as the basic and the foundation for their activities in enjoying the process of learning.

For the English teachers particularly the teachers of speaking, the last three keys, smile, thank God and love, can be made as a password during the learning in the classroom. The teachers could implant those 3 keys to the students with a hand gesture forming like a smile when yelling the word 'smile', with a hand gesture forming like someone praying (raising both of hands) when saying 'thank God', and with a hand gesture forming like 'a heart' as the symbol of love when saying the word 'love'. Implant to them that those 3 keys could be made as first step and first attitude in facing the difficulties and the challenges in learning English and in doing the tasks given by the teachers. For instance, when the students are sullen and complain becuase of the tasks given by their teachers, spontaneously the teachers yell 'smile, thank God and love' followed by the hand gestures as the antidote for their complain. The teachers command the students to yell their 'smile, thank God and love'.

\section{References}

Al-Khalili, Jim, Philippa Perry, Julian Baggini, Jojo Moyes, and Catherine Wybourne. "What Is Love? Five Theories on the Greatest Emotion of All." The Guardian, December 13, 2012, sec. Comment is free. http://www.theguardian.com/com mentisfree/2012/dec/13/what-islove-five-theories.

Brown, H. Douglas. Teaching by Principles: An Inteactive Approach to Language Pedagody (2nd Ed.). New York: Addison Wesley Longman, Inc., 2001.

http://www.amazon.com/Principle s-Language-Learning-Teaching5th/dp/0131991280/ref=sr_1_1?i e $=U T F 8 \&$ qid $=1448005931 \& \overline{s r}=8$ - 
$1 \&$ keywords $=$ principle + of + langua ge+teaching+douglas+brown.

Cambridge Advanced Learner's Dictionary 3rd Edition. English. Cambridge: Cambridge University Press, 2008. http://dictionary.cambridge.org/di ctionary/british/.

Childs, Leslie. Academic Studies English: Support Material for Materials and Exercises for Speakingand Listening. 1st ed. Canada, 1999.

Dulay, Heidi, Marina Burt, and Stephen Krashen. Language Two. New York: Oxford University Press, 1982.

http://www.amazon.com/Languag e-Two-HeidiDulay/dp/0195025539/ref=sr_1_1 ?ie.

Gebhard, Jerry G. Teaching English as a Foreign or Second Language, Second Edition: A Teacher SelfDevelopment and Methodology Guide. Michigan: the Michigan University, 1998. http://www.amazon.com/Teachin g-English-Foreign-SecondLanguage/dp/0472031031/ref=sr 1_1?ie=UTF8\&qid $=1448028442$ 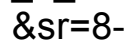

$1 \&$ keywords $=$ Teaching + English + as $+a+$ Foreign+or+Second+Lang uage $\% 3 \mathrm{~A}+\mathrm{A}+\mathrm{Teacher}+$ Selfdevelopment+and+Methodology+ Guide+by+gebhard.
"Giving Thanks to Allah Is a Blessing - Al Quran Classes." Accessed November 23, 2015. https://www.alquranclasses.com/ giving-thanks-to-allah-blessing/.

Kachru, Braj B. "World Englishes: Approaches, Issues, and Resources. Language Teaching 25.1(1992): 1-14" 25.1 (1992): 114.

"Laughter Is the Best Medicine: The Health Benefits of Humor and Laughter." Accessed November 23, 2015. http://www.helpguide.org/articles/ emotional-health/laughter-is-thebest-medicine.htm.

Lightbown, Nina Spada, Patsy M., and Nina Spada. How Languages Are Learned. Oxford: Oxford University Press, 1999.

Mattarima, Karim, and Abdul Rahim Hamdan. 'Learners' Motivation And Learning Strategies In English Foreign Language (EFI) In Indonesian Context" 1 (September 2011): 100-108.

Thornbury, Scott. How to Teach Speaking. Oxford: Macmillan Education, 2005.

Wafi, Abdul. Terapi Ngomong Inggris: Jalan Pintas Bisa Berbicara Bahasa Inggris. Yogyakarta: Pustaka IImu, 2015. 